\title{
Performance of 'Okitsu' satsuma mandarin trees on different rootstocks in Northwestern Paraná State
}

\section{Comportamento de tangerineira satsuma 'Okitsu' sobre diferentes porta-enxertos no Noroeste do Paraná}

\author{
Zuleide Hissano Tazima ${ }^{1 *}$; Carmen Silvia Vieira Janeiro Neves ${ }^{2}$; \\ Inês Fumiko Ubukata Yada'; Rui Pereira Leite Júnior ${ }^{4}$
}

\begin{abstract}
In the state of Paraná, 'Rangpur lime' is the main citrus rootstock, which has provided good performance for trees of different cultivars planted in the State. However, rootstock diversification is needed as well as to identify the best ones for citrus cultivars less explored commercially yet. The objective of this study was to evaluate the vegetative growth, yield and fruit quality of 'Okitsu' satsuma mandarin trees (Citrus unshiu Marc.) grafted on nine rootstocks in the Northwest region of the state of Paraná, Brazil. The orchard was established in the Paranavaí Experimental Station of the Agronomic Institute of Paraná, Paranavaí, PR, on January 2001. The experimental design was randomized blocks with nine treatments, three replications, and two trees per plot. The rootstocks included in this study were 'Rangpur' lime (Citrus limonia Osb.), 'Cleópatra' mandarin (Citrus reshni hort. ex Tanaka), 'C-13' citrange [Citrus sinensis $\times$ Poncirus trifoliata orange (L.) Raf.], 'Volkamer' lemon (Citrus volkameriana V. Ten. e Pasq.), 'Carrizo' citrange [C. sinensis $\times$ P. trifoliata (L.) Raf.], 'Sunki' mandarin (Citrus sunki hort. ex Tanaka), 'Trifoliate' orange [P. trifoliata (L.) Raf. ], 'Swingle' citrumelo [Citrus paradisi Macfad. cv. Duncan $\times$ P. trifoliata (L.) Raf.], and 'Caipira DAC' sweet orange [C. sinensis (L.) Osb.]. The largest tree canopy was induced by 'Cleópatra' mandarin and the lowest by 'Trifoliate' orange, with $37.1 \mathrm{~m}^{3}$ and $9.9 \mathrm{~m}^{3}$ of tree canopy, respectively. The highest relationship between scion and rootstock trunk diameter was observed for trees grafted on 'Swingle' citrumelo. The largest cumulative yields over eight seasons were induced by 'Volkamer' lemon, 'Rangpur' lime, 'Caipira DAC' sweet orange, 'Cleópatra' mandarin, and 'Carrizo' citrange, ranging from 867.3 to $989.6 \mathrm{~kg}$ per tree. These rootstocks also induced the largest fruit mass, along with 'Sunki', ranging from 173.3 to $188.0 \mathrm{~g}$. 'Trifoliate' orange induced cumulative yield of only $52.5 \%$ in relation to 'Rangpur lime'. 'Rangpur' lime, 'Carrizo' citrange, 'Trifoliate' orange and 'Swingle' citrumelo induced the largest TSS/TTA ratios, ranging from 10.41 to 10.79 . For orchard planning, trees on 'Cleópatra' mandarin require the largest tree spacing both in and between rows, while the smallest tree spacing is required for trees on 'Trifoliate' orange. The theoretical yield estimated, according to the appropriate spacing for each rootstock ranged from 95.6 to $152.1 \mathrm{t} \cdot \mathrm{ha}^{-1}$.
\end{abstract}

Key words: Citrus unshiu, vegetative growth, yield, fruit quality

\footnotetext{
${ }^{1}$ Eng $^{\text {a }}$ Agra , Pesquisadora Dra ${ }^{\text {a }}$ Área de Ecofisiologia, Instituto Agronômico do Paraná, IAPAR, Londrina, PR. E-mail: zuleide@ iapar.br

${ }^{2}$ Eng $^{\mathrm{a}}$ Agr ${ }^{\mathrm{a}}$, Prof ${ }^{\mathrm{a}}$ Dr $^{\mathrm{a}}$ Adjunto, Dept ${ }^{\mathrm{o}}$ de Agronomia, Universidade Estadual de Londrina, UEL, Londrina, PR. E-mail: csvjneve@ uel.br

${ }_{3}^{3}$ Matemática, M.e, Área de Biometria, IAPAR, Londrina, PR. E-mail: inesyada@iapar.br

${ }^{4}$ Eng $^{\mathrm{o}}$ Agr ${ }^{\circ}$, Pesquisador Dr., Área de Proteção de Plantas, IAPAR, Londrina, PR. E-mail: ruileite@iapar.br

* Author for correspondence
} 


\section{Resumo}

O limoeiro 'Cravo' é o principal porta-enxerto utilizado para citros no estado do Paraná e tem apresentado bom desempenho para as diferentes cultivares de copa. Porém, são necessários estudos para diversificar os porta-enxertos utilizados no Estado e também para serem utilizados em cultivares ainda pouco exploradas comercialmente. O objetivo deste estudo foi avaliar o desenvolvimento vegetativo, a produção e a qualidade de frutos da tangerineira satsuma 'Okitsu' (Citrus unshiu Marc.) enxertada sobre diferentes porta-enxertos. O pomar foi implantado na Estação Experimental de Paranavaí do Instituto Agronômico do Paraná - IAPAR, em Paranavaí, PR, em janeiro de 2001. O delineamento experimental foi de blocos ao acaso, com nove tratamentos, três repetições e duas plantas úteis por parcela. Os porta=enxertos utilizados foram limoeiro 'Cravo' (Citrus limonia Osb.), tangerineira 'Cleópatra' (Citrus reshni hort. ex Tanaka), citrangeiro 'C-13' [Citrus sinensis x Poncirus trifoliata (L.) Raf.], limoeiro 'Volkameriano' (Citrus volkameriana V. Ten. e Pasq.), citrangeiro 'Carrizo' [C. sinensis x P. trifoliata (L.) Raf.], tangerineira 'Sunki' (Citrus sunki hort. ex Tanaka), trifoliata [P. trifoliata (L.) Raf.], citrumeleiro 'Swingle' [Citrus paradisi Macfad. cv. Duncan x P. trifoliata (L.) Raf.] e laranjeira 'Caipira DAC' [C. sinensis (L.) Osb.]. O maior volume de copa das plantas de satsuma 'Okitsu' foi induzido pela tangerineira 'Cleópatra' com $37,1 \mathrm{~m}^{3}$, e o menor foi para as plantas enxertadas em 'Trifoliata', com 9,9 $\mathrm{m}^{3}$. O citrumeleiro 'Swingle' proporcionou maior relação entre diâmetro do tronco abaixo e acima do ponto de enxertia. As maiores produções acumuladas em oito safras foram induzidas por limoeiros 'Volkameriano' e 'Cravo', laranjeira 'Caipira DAC', tangerineira 'Cleópatra' e citrangeiro 'Carrizo', com valores entre 867,3 kg e 989,6 kg. Esses porta-enxertos, juntamente com a tangerineira 'Sunki', induziram a produção de frutos com as maiores massas, de 173,3 a 188,0 g. O 'Trifoliata' induziu produção acumulada de 52,5 \% em relação ao de plantas sobre o limoeiro 'Cravo'. Os portaenxertos limoeiro 'Cravo', citrangeiro 'Carrizo', trifoliata e citrumeleiro 'Swingle' induziram valores significativamente maiores para ratio (SST/ATT), com valores ente 10,41 e 10,79. Para planejamento de um pomar, plantas de tangerineira satsuma 'Okitsu' sobre o porta-enxerto tangerineira 'Cleópatra' necessitam de maior espaçamento entre linhas e entre plantas, enquanto sobre trifoliata requerem espaçamentos menores. A produtividade teórica, calculada para o espaçamento adequado para cada porta-enxerto, variou de 95,6 a 152,1 $\mathrm{t} \mathrm{ha}^{-1}$ para os nove porta-enxertos.

Palavras-chave: Citrus unshiu, desenvolvimento vegetativo, produção, qualidade de fruto

\section{Introduction}

Mandarin is the second most important group of citrus planted in Brazil, with production to attend basically the internal fresh fruit market. In contrast, the oranges, the most important group, are produced mainly for industrial processing to produce frozen concentrated juice. The state of São Paulo is the largest mandarin producer with 12,334 ha and production of 362,968 tons, followed by the state of Paraná, with 10,087 ha and production of 171,986 tons, and Minas Gerais, with 7,060 ha and production of 146,657 tons, in the 2012 season (IBGE, 2014).

In the state of Paraná, there are distinct areas of citrus production. The North and Northwest regions of the State produce mainly oranges for industrial processing. Some of the oranges also supply the internal fresh fruit market, as well as the fresh fruit market of neighboring States. Despite this, in some areas of the North region of Paraná, more specifically the Nova América da Colina area, oranges are produced primarily for the fresh fruit market. Furthermore, in the Northwest region some areas specialized in the production of Tahiti acid lime, while in the Vale do Ribeira region the Ponkan mandarin is the main citrus cultivated.

'Okitsu' satsuma (Citrus unshiu Marc.) is another mandarin produced in the state of Paraná. Further, this mandarin is a seedless and early maturing cultivar, resistant to citrus canker (TAZIMA; LEITE JUNIOR, 2002). 'Okitsu' satsuma mandarin has also relative commercial importance in Argentina, Japan, and the United States (FADAMIRO; NESBITT; WALL, 2007). Although no statistical 
data regarding the Brazilian production of seedless mandarins is available to date, the market for this type of citrus fruit has potential for growth, as happened with other kind of fruits (MORAES, 2007).

In the State of Paraná, the area planted with 'Okitsu' satsuma mandarin is still restricted and the trees are grafted exclusively on 'Rangpur' lime (Citrus limonia Osb.) rootstock. This rootstock provides rusticity, high productivity and longevity to the citrus trees, adapts well to both sandy and clay soils, and is tolerant to drought and diseases such as citrus tristeza (OLIVEIRA et al., 2008). In other countries, as Argentina and Japan, the 'Okitsu' satsuma mandarin trees are usually grafted on 'Carrizo' citrange [Citrus sinensis $\times$ Poncirus trifoliata (L.) Raf.] and trifoliate orange [P. trifoliata (L.) Raf.], respectively (FADAMIRO; NESBITT; WALL, 2007). These rootstocks induce a better fruit quality, regardless of the citrus cultivar (POMPEU JUNIOR, 2005).

The use of only a few rootstocks poses a high risk for citrus production (OLIVEIRA et al., 2008). Therefore, the diversification of citrus rootstock is of utmost importance for any citrus producing region. This procedure has the objective to avoid such problems as the one occurred in the late 1930s, when around $80 \%$ of citrus trees in the state of São Paulo died because they were grafted in only one rootstock, the Sour orange (Citrus aurantium L.), which was highly susceptible to citrus tristeza disease (ROSSETTI, 2001).

The objective of this study was to evaluate the performance of 'Okitsu' satsuma mandarin grafted on nine different rootstocks in terms of tree vegetative growth and production, and fruit characteristics in the Northwest region of the state of Paraná, Brazil.

\section{Material and Methods}

The experiment was carried out in the Paranavaí Experimental Station of the Agronomic Institute of
Paraná, located in Paranavaí, PR, at the latitude of $23^{\circ}$ $05^{\prime} \mathrm{S}$, longitude of $52^{\circ} 26^{\prime} \mathrm{W}$ and altitude of $480 \mathrm{~m}$, on a Typic Haplustox soil. The climate is classified as $\mathrm{Cfa}$, with average annual high temperature of $28.4^{\circ} \mathrm{C}$ and low temperature of $17.8^{\circ} \mathrm{C}$. The total annual precipitation average is $1,500 \mathrm{~mm}$, with the highest concentration of rainfall in the spring and summer, and the monthly average relative humidity is $69.1 \%$ (IAPAR, 2011).

The trees of 'Okitsu' satsuma mandarin (Citrus unshiu Marc.) were produced in a citrus nursery at Londrina Experimental Station of the Paraná Agronomic Institute, in Londrina, PR. The 'Okitsu' satsuma mandarin buds and seeds of the rootstock were obtained from the Active Citrus Germplasm Bank, located in the same Londrina Experimental Station. 'Okitsu' satsuma mandarin buds were grafted on nine different rootstocks, including 'Rangpur lime' (Citrus limonia Osb.), 'Cleópatra' mandarin (Citrus reshni hort. ex Tanaka), 'C-13' citrange [Citrus sinensis $\times$ Poncirus trifoliata (L.) Raf.], 'Volkamer' lemon (Citrus volkameriana V. Ten. e Pasq.), 'Carrizo' citrange [C. sinensis $\times$ P. trifoliata (L.) Raf.], 'Sunki' mandarin (Citrus sunki hort. ex Tanaka), 'Trifoliate' orange [P. trifoliata (L.) Raf.], 'Swingle' citrumelo [Citrus paradisi Macfad. cv. Duncan $\times P$. trifoliata (L.) Raf.], and Caipira DAC sweet orange [C. sinensis (L.) Osb.].

The experimental orchard was planted on January 2001 in a spacing of $7.0 \mathrm{~m} \times 6.0 \mathrm{~m}$, with a total of 238 trees $\mathrm{ha}^{-1}$. The trees received phytosanitary treatments and fertilization as recommended for the Northwestern region of the state of Paraná, Brazil (IAPAR, 1992). The orchard was established without irrigation, pruning, or thinning of the fruits. The control of invasive plants was carried out with a manual mower. The experimental design was randomized blocks, with nine treatments, three replications, and two trees per plot.

The trees were evaluated for their vegetative growth in the month of July in 2009 and 2010. To determine the canopy diameter, two measurements 
were taken in the middle part of the tree using a graduated scale. One measurement was taken in the direction of the planting row and the other perpendicular to the row. Tree height was determined by measuring the distance from the ground to the top of the tree. The canopy volume (V) was determined using the equation $\mathrm{V}=2 / 3 \pi \mathrm{R}^{2} \mathrm{H}$ (MENDEL, 1956), where $\mathrm{R}$ is the canopy radius and $\mathrm{H}$ the tree height.

The trunk circumference was measured 10.0 $\mathrm{cm}$ above and $10.0 \mathrm{~cm}$ below the graft line with a measuring tape. The trunk circumference data were used for subsequent calculation of the ratio between the diameters below and above the graft line.

Production was determined by counting the number of fruits and weighting these fruits using a digital scale (Líder ${ }^{\circledR}$, PR 30 model) with a $50 \mathrm{~kg}$ capacity, for the harvests from 2003 through 2010. Based on the data regarding canopy volume in $\mathrm{m}^{3}$ and yield, the average productive efficiency $(\mathrm{kg}$ $\mathrm{m}^{-3}$ ) of the tree was determined for the harvests of 2009 and 2010. The determination of the yield alternation index (I) was performed using the Pearce and Dobersek-Urbanc (1967) equation, I = $1 /(n-1) \times\{(a 2-a 1) /(a 2+a 1)+(a 3-a 2) /(a 3+a 2)+\ldots$ $+(\mathrm{a}(\mathrm{n})-\mathrm{a}(\mathrm{n}-1)) /(\mathrm{a}(\mathrm{n})+\mathrm{a}(\mathrm{n}-1))\}$, where $\mathrm{n}=$ number of years, and a1, a2, ... a(n-1), a(n) = yield in the corresponding years.

To perform the physical and chemical analysis of the fruits, samples of 10 fruit were randomly collected from the external part of the trees at 1.0 to $2.0 \mathrm{~m}$ from the ground, on February of each year from 2006 through 2010. The average fruit mass was determined by dividing the total weight of the fruits from each tree by the respective number of harvested fruits. The measurements of the longitudinal diameter (LD) and equatorial diameter (ED) of the fruits were performed with a Mitutoyo ${ }^{\circledR}$ digital pachymeter, ABS model, $300 \mathrm{~mm} \times 12$ inches. The juice yield, expressed as in percentage, was determined by the ratio $=(\mathrm{JM} / \mathrm{FM}) \times 100$, where $\mathrm{JM}=$ juice mass $(\mathrm{g})$ and $\mathrm{FM}=$ fruit mass $(\mathrm{g})$. The juice was extracted using a Croydon ${ }^{\circledR}$ extractor, ES4EA-B60000 model.
The content of total soluble solids (TSS) was determined using a digital Atago ${ }^{\circledR}$ refractometer PAL-3 (0-93) model, expressing the results in ${ }^{\circ}$ Brix. The total titratable acidity (TTA) in percentage of citric acid was determined by titrating $25 \mathrm{~mL}$ of juice with $0.1 \mathrm{~N}$ sodium hydroxide solution in an automatic titrator (AOAC, 1990). The ratio was determined based on the relation between the content of total soluble solids (TSS) and the total titratable acidity (TTA). The technological index (TI), or the amount $(\mathrm{kg})$ of total soluble solids present in a 40.8 $\mathrm{kg}$ harvest box, was calculated by the equation TI $=($ juice yield $\times$ total soluble solids $\times 40.8) / 10.000$, where: juice yield $=$ ratio $\mathrm{JM} / \mathrm{FM} \times 100$, soluble solids $=$ content in total soluble solids (DI GIORGI et al., 1990). To calculate the industrial yield (IY), or the number of boxes of fruits needed to produce a ton of concentrated juice with $66^{\circ} \mathrm{Brix}$, the equation IY $=660 /$ TI was used, where 660 corresponds to $660 \mathrm{~kg}$ of total soluble solids contained in $1,000 \mathrm{~kg}$ of concentrated juice.

For planning the establishment of new orchards, the theoretical number of trees $\mathrm{ha}^{-1}$ was calculated according to the equation of De Negri and Blasco (1991), $\mathrm{E}=(\mathrm{D} \times 0.75) \times(\mathrm{D}+2.5)$, where $\mathrm{E}=$ theoretical appropriate spacing and $\mathrm{D}=$ average canopy diameter for each combination canopy/ rootstock. The calculation considers an overlap of $25 \%$ of the tree branches in the planting row and a clearance distance of $2.5 \mathrm{~m}$ between rows, which would be sufficient to allow cultural practices to be performed. Fruit yield was also estimated for the theoretical number of trees ha-1.

The data were subjected to analysis of variance and means were compared based on the Scott-Knott test, with a significance level of 5\% using the SAS (SAS Institute, 2001) and SISVAR (FERREIRA, 2000) softwares.

\section{Results and Discussion}

'Cleópatra' mandarin provided the highest canopy growth for the 'Okitsu' satsuma mandarin 
trees, considering canopy volume, height, and diameter of the tree (Table 1). In a study with the same cultivar grafted on nine different rootstocks under the conditions of Londrina, PR, Tazima et al. (2013) also observed that 'Cleópatra' induced a large canopy volume, along with the rootstock 'Caipira DAC'. In contrast, the lowest vegetative growth of the trees was induced by 'Trifoliate' orange (Table 1). Tazima et al. (2013) also observed that 'Trifoliate' orange, as well as 'Rangpur' lime and 'Volkamer' lemon, induced a small canopy for 'Okitsu' satsuma mandarin, with no differences among them. Studies with 'Yamakawa' satsuma mandarin on seven rootstocks also revealed poor development of trees grafted on 'Trifoliate' orange (NODA et al., 2001). 'Trifoliate' orange is considered a rootstock with large potential to reduce tree size, though this characteristic can be expressed depending on other factors, such as soil and climate conditions, canopy cultivar, the presence of viruses in the propagative material, and the use of irrigation (POMPEU JÚNIOR, 2005). Therefore, the tree size is very important from the point of view of planning new orchards, because there is a possibility of increasing the number of trees per unit of area, and the grower can have a fast return of the investment made to establish the orchard.

Table 1. Tree height, canopy diameter and canopy volume of 'Okitsu' satsuma mandarin trees grafted on different rootstocks in Paranavaí, PR, for the 2009 and 2010 seasons.

\begin{tabular}{lccc}
\hline \multicolumn{1}{c}{ Rootstock } & Tree height $(\mathrm{m})$ & Canopy diameter $(\mathrm{m})$ & Canopy volume $\left(\mathrm{m}^{3}\right)$ \\
\hline 'Rangpur' lime & $3.0 \mathrm{~b}^{\mathrm{z}}$ & $4.1 \mathrm{~b}$ & $26.7 \mathrm{~b}$ \\
'Cleópatra' mandarin & $3.4 \mathrm{a}$ & $4.5 \mathrm{a}$ & $37.1 \mathrm{a}$ \\
'C-13' citrange & $3.0 \mathrm{~b}$ & $4.1 \mathrm{~b}$ & $26.3 \mathrm{~b}$ \\
'Volkamer' lemon & $3.0 \mathrm{~b}$ & $3.8 \mathrm{~b}$ & $23.0 \mathrm{~b}$ \\
'Carrizo' citrange & $3.3 \mathrm{a}$ & $3.8 \mathrm{~b}$ & $24.9 \mathrm{~b}$ \\
'Sunki' mandarin & $3.5 \mathrm{a}$ & $3.7 \mathrm{~b}$ & $24.6 \mathrm{~b}$ \\
'Trifoliate' orange & $2.3 \mathrm{c}$ & $2.8 \mathrm{~d}$ & $9.9 \mathrm{~d}$ \\
'Swingle' citrumelo & $2.9 \mathrm{~b}$ & $3.3 \mathrm{c}$ & $16.9 \mathrm{c}$ \\
'Caipira DAC'sweet orange & $3.4 \mathrm{a}$ & $3.9 \mathrm{~b}$ & $27.1 \mathrm{~b}$ \\
\hline CV $(\%)$ & 5.3 & 5.6 & 10.6 \\
\hline
\end{tabular}

${ }^{z}$ Means followed by the same letter in the column are not significantly different at 0.05 level by Scott-Knott test.

Source: Elaborated by the authors.

Trunk diameter above and below the graft line was significantly lower for 'Okitsu' satsuma mandarin grafted on 'Trifoliate' orange as compared with the other rootstocks (Table 2), in agreement with the results obtained by Tazima et al. (2013). On the other hand, trees on 'Cleópatra' mandarin presented a significantly larger trunk diameter above the graft line, followed by the trees on 'Rangpur' lime and 'Caipira DAC' sweet orange (Table 2), as a result of the vigor of the trees on these rootstocks.
The highest ratio between trunk diameter below and above the graft line was observed for the trees on 'Swingle' citrumelo, differing significantly from the ratio presented by the trees grafted on the others rootstocks (Table 2). Although this ratio may indicate a difference in vigor between the canopy and the rootstock, this difference between trunk diameter above and below the graft line is not always related to any kind of incompatibility between canopy and rootstock (BARBASSO; PIO; CARVALHO, 2005). 
Table 2. Trunk diameter below and above the graft line, and ratio between trunk diameter bellow and above the graft line of 'Okitsu' satsuma mandarin trees grafted on different rootstocks in Paranavaí, PR, for the 2009 and 2010 seasons.

\begin{tabular}{|c|c|c|c|}
\hline \multirow[t]{2}{*}{ Rootstock } & \multicolumn{2}{|c|}{$\begin{array}{l}\text { Trunk diameter at } 10 \mathrm{~cm} \text { from the graft line } \\
\qquad(\mathrm{cm})\end{array}$} & \multirow[t]{2}{*}{$\begin{array}{c}\text { Trunk diameter } \\
\text { ratio }^{Y}\end{array}$} \\
\hline & Below & Above & \\
\hline 'Rangpur' lime & $18.2 \mathrm{a}^{\mathrm{z}}$ & $16.2 \mathrm{~b}$ & $1.12 \mathrm{~d}$ \\
\hline 'Cleópatra' mandarin & $19.8 \mathrm{a}$ & $17.8 \mathrm{a}$ & $1.12 \mathrm{~d}$ \\
\hline 'C-13' citrange & $20.5 \mathrm{a}$ & $14.2 \mathrm{c}$ & $1.46 \mathrm{~b}$ \\
\hline 'Volkamer' lemon & $16.7 \mathrm{a}$ & $14.7 \mathrm{c}$ & $1.15 \mathrm{~d}$ \\
\hline 'Carrizo' citrange & $18.3 \mathrm{a}$ & $13.4 \mathrm{c}$ & $1.37 \mathrm{c}$ \\
\hline 'Sunki' mandarin & $17.3 \mathrm{a}$ & $15.3 \mathrm{c}$ & $1.14 \mathrm{~d}$ \\
\hline 'Trifoliate' orange & $13.3 \mathrm{~b}$ & $9.3 \mathrm{e}$ & $1.47 \mathrm{~b}$ \\
\hline 'Swingle' citrumelo & $17.7 \mathrm{a}$ & $11.3 \mathrm{~d}$ & $1.56 \mathrm{a}$ \\
\hline 'Caipira DAC' sweet orange & $18.7 \mathrm{a}$ & $16.0 \mathrm{~b}$ & $1.18 \mathrm{~d}$ \\
\hline CV $(\%)$ & 7.2 & 6.1 & 3.6 \\
\hline
\end{tabular}

${ }^{z}$ Means followed by the same letter in the column are not significantly different at 0.05 level by Scott-Knott test.

${ }^{\mathrm{Y}}$ Ratio of trunk diameter $10 \mathrm{~cm}$ below and $10 \mathrm{~cm}$ above the graft line.

Source: Elaborated by the authors.

The annual yield of 'Okitsu' satsuma mandarin trees on the rootstocks studied did not differ significantly for the 2003, 2005, 2006, 2007, and 2010 seasons. In 2004, productions of the trees on the rootstocks 'Rangpur' lime, 'Volkamer' lemon, and 'Carrizo' citrange did not differ, but were significantly higher than those of the trees on the others rootstocks (Table 3). In 2008 and 2009 seasons, the trees on the rootstocks 'Rangpur' lime, 'Volkamer' lemon, 'C-13' citrange, and 'Caipira DAC' sweet orange had higher yield than those on the others rootstocks (Table 3). Trees on 'Cleópatra' and 'Sunki' mandarins, and 'Carrizo' citrange also had such higher yield in the 2009 season (Table 3). For the seasons of 2008 and 2009, trees on the rootstocks 'Trifoliate' orange and 'Swingle' citrumelo showed the poorest yields, differing significantly from the others trees (Table 3); additionally, in 2008, trees on 'Cleópatra', 'Carrizo', and 'Sunki' rootstocks also had significantly lower yields, although there was no difference among the trees on these three rootstocks (Table 3). The lower production of the trees on some rootstocks can be due to the occurrence of drought during the growth seasons. In 2007, we had 14.7 and $3.2 \mathrm{~mm}$ of rainfall and $57 \%$ and $48 \%$ of relative humidity for the months of August and September, respectively (IAPAR, 2011). Nogueira (1979) stated that high temperatures, low air humidity, and soil drought during flowering can favor flower abscission. Therefore, trees on rootstocks that are more affected by drought conditions, such as 'Trifoliate' orange and 'Swingle' citrumelo, induced lower yields. These results are consistent with previous information on drought tolerance of the citrus rootstocks (POMPEU JÚNIOR, 2005).

Considering the average yield and the cumulative production during the period from 2003 through 2010, the rootstocks that provided the highest yields for the 'Okitsu' satsuma mandarin trees were 'Rangpur' lime, 'Volkamer' lemon, 'Cleópatra' mandarin, 'Carrizo' citrange and 'Caipira DAC' sweet orange. These rootstocks were significantly superior to the others in terms of yield. These rootstocks have been reported to induce good yields to different citrus cultivars with the exception of 'Carrizo' citrange (POMPEU JÚNIOR, 1991). However, a high yield was also observed for 'Okitsu' satsuma mandarin trees grafted on 'Carrizo' citrange in a study carried out in Japan (NODA et al., 2001), suggesting that this may be a good tree combination for this mandarin. 
Table 3. Annual production of 'Okitsu' satsuma mandarin grafted on different rootstocks in Paranavaí, PR, for the period from 2003 through 2010.

\begin{tabular}{|c|c|c|c|c|c|c|c|c|c|c|c|c|c|c|c|}
\hline \multirow[t]{2}{*}{ Rootstock } & \multicolumn{15}{|c|}{ Yield (kg per tree) } \\
\hline & 2003 & & 2004 & & 2005 & & 2006 & & 2007 & & 2008 & & 2009 & & 2010 \\
\hline 'Rangpur' lime & 10.1 & $a^{z}$ & 14.7 & $\mathrm{a}$ & 70.2 & $\mathrm{a}$ & 135.9 & $\mathrm{a}$ & 212.0 & $\mathrm{a}$ & 108.9 & $\mathrm{a}$ & 202.6 & $\mathrm{a}$ & $226.2 \mathrm{a}$ \\
\hline 'Cleópatra' mandarin & 6.8 & a & 5.3 & $\mathrm{~b}$ & 54.0 & $\mathrm{a}$ & 62.8 & $\mathrm{a}$ & 158.3 & $\mathrm{a}$ & 86.9 & b & 261.4 & $\mathrm{a}$ & $261.7 \mathrm{a}$ \\
\hline 'C-13' citrange & 5.2 & $\mathrm{a}$ & 6.8 & $\mathrm{~b}$ & 15.1 & $\mathrm{a}$ & 62.3 & $\mathrm{a}$ & 140.5 & $\mathrm{a}$ & 100.1 & $\mathrm{a}$ & 195.6 & $\mathrm{a}$ & $184.2 \mathrm{a}$ \\
\hline 'Volkamer' lemon & 4.7 & $\mathrm{a}$ & 18.0 & $\mathrm{a}$ & 65.1 & $\mathrm{a}$ & 92.7 & $\mathrm{a}$ & 178.4 & $\mathrm{a}$ & 159.4 & $\mathrm{a}$ & 211.3 & $\mathrm{a}$ & $260.1 \mathrm{a}$ \\
\hline 'Carrizo' citrange & 8.3 & $\mathrm{a}$ & 13.6 & $\mathrm{a}$ & 43.1 & $\mathrm{a}$ & 61.9 & $\mathrm{a}$ & 159.3 & $\mathrm{a}$ & 38.7 & $\mathrm{~b}$ & 220.5 & $\mathrm{a}$ & 321.9 a \\
\hline 'Sunki' mandarin & 9.3 & $\mathrm{a}$ & 4.4 & $\mathrm{~b}$ & 31.3 & $\mathrm{a}$ & 87.9 & $\mathrm{a}$ & 177.1 & $\mathrm{a}$ & 54.9 & $\mathrm{~b}$ & 204.2 & $\mathrm{a}$ & $189.6 \mathrm{a}$ \\
\hline 'Trifoliate' orange & 3.3 & $\mathrm{a}$ & 1.8 & $\mathrm{~b}$ & 23.0 & $\mathrm{a}$ & 54.5 & $\mathrm{a}$ & 117.9 & a & 66.7 & b & 118.0 & $\mathrm{~b}$ & $129.5 \mathrm{a}$ \\
\hline 'Swingle' citrumelo & 10.2 & $\mathrm{a}$ & 4.1 & $\mathrm{~b}$ & 34.8 & 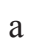 & 50.6 & $\mathrm{a}$ & 116.5 & $\mathrm{a}$ & 46.3 & b & 150.2 & $\mathrm{~b}$ & $190.1 \mathrm{a}$ \\
\hline $\begin{array}{l}\text { 'Caipira DAC' sweet } \\
\text { orange }\end{array}$ & 6.1 & & 4.8 & $\mathrm{~b}$ & 40.2 & $\mathrm{a}$ & 67.4 & $\mathrm{a}$ & 148.0 & $\mathrm{a}$ & 133.9 & $\mathrm{a}$ & 253.2 & $\mathrm{a}$ & 305.5 a \\
\hline CV $(\%)$ & 53.4 & & & & & & & & & & & & 15.4 & & 30.6 \\
\hline
\end{tabular}

${ }^{\mathrm{z}}$ Means followed by the same letter in the column are not significantly different at 0.05 level by Scott-Knott test.

Source: Elaborated by the authors.

'Swingle' citrumelo also induced lower production than the 'Rangpur' lime to Fallglo mandarin trees in a study carried out in Bebedouro, SP(MOURÃO FILHO etal., 2007). In another study, trees of 'Okitsu' satsuma mandarin on 'Swingle' citrumelo produced $85.7 \mathrm{t} \cdot \mathrm{ha}^{-1}$ and was significantly superior to the ones on 'Sunki' mandarin and 'Flying Dragon' trifoliate with productions of 43.8 and 35.8 $\mathrm{t} \cdot \mathrm{ha}^{-1}$, respectively (CANTUARIAS-AVILÉS et al., 2010).

Regarding the relative cumulative yield, the production of the trees on 'Trifoliate' orange was $52.5 \%$ lower than the trees grafted on 'Rangpur' lime (Table 4). These results confirm previous observations regarding trees on 'Trifoliate' orange, that may induce the development of vigorous trees when grafted with healthy nucellar clones, though these trees are always smaller than with the ones on other rootstocks, and consequently have lower fruit production yield (POMPEU JÚNIOR, 2005)

The alternation yield index varied between 0.2 and 0.3 for the 'Okitsu' satsuma mandarin trees on the different rootstocks and no significant differences were observed for this variable among rootstocks (Table 4). The alternation yield index can vary from 0 to 1 , as the value closest to zero indicating lower yield alternation. Therefore, 'Okitsu' satsuma mandarin trees did not show an important yield alternation under the conditions of this study. 
Table 4. Cumulative yield, relative cumulative yield, mean of the yield and alternation yield index for 'Okitsu' satsuma mandarin trees grafted on different rootstocks in Paranavaí, PR, for the period from 2003 through 2010.

\begin{tabular}{lccrcc}
\hline Rootstock & \multicolumn{4}{c}{ Yield } & \\
\cline { 2 - 4 } & $\begin{array}{c}\text { Cumulative } \\
(k g \text { per tree })\end{array}$ & $\begin{array}{c}\text { Relative } \\
\text { Cumulative (\%) }\end{array}$ & $\begin{array}{c}\text { Mean } \\
\text { (kg per tree) }\end{array}$ & $\begin{array}{c}\text { Alternation } \\
\text { Index }\end{array}$ \\
\hline 'Rangpur' lime & $980.5 \mathrm{a}^{\mathrm{z}}$ & 100.0 & $122.6 \mathrm{a}$ & $0.2 \mathrm{a}$ \\
'Cleópatra' mandarin & $897.2 \mathrm{a}$ & 91.5 & $112.1 \mathrm{a}$ & $0.2 \mathrm{a}$ \\
'C-13' citrange & $709.9 \mathrm{~b}$ & 72.4 & $88.7 \mathrm{~b}$ & $0.2 \mathrm{a}$ \\
'Volkamer' lemon & $989.6 \mathrm{a}$ & 100.9 & $123.7 \mathrm{a}$ & $0.3 \mathrm{a}$ \\
'Carrizo' citrange & $867.3 \mathrm{a}$ & 88.5 & $108.4 \mathrm{a}$ & $0.2 \mathrm{a}$ \\
'Sunki' mandarin & $758.9 \mathrm{~b}$ & 77.4 & $94.9 \mathrm{~b}$ & $0.2 \mathrm{a}$ \\
'Trifoliate' orange & $514.6 \mathrm{~b}$ & 52.5 & $64.3 \mathrm{~b}$ & $0.2 \mathrm{a}$ \\
'Swingle' citrumelo & $602.7 \mathrm{~b}$ & 61.5 & $75.3 \mathrm{~b}$ & $0.2 \mathrm{a}$ \\
'Caipira DAC' sweet orange & $959.0 \mathrm{a}$ & 97.8 & $119.9 \mathrm{a}$ & $0.2 \mathrm{a}$ \\
\hline CV (\%) & 14.4 & & 13.2 & 17.8 \\
\hline
\end{tabular}

${ }^{\mathrm{z}}$ Means followed by the same letter in the column are not significantly different at 0.05 level by Scott-Knott test.

Source: Elaborated by the authors.

The rootstocks that induced the highest fruit mass were 'Rangpur' lime, 'Volkamer' lemon, 'Cleópatra' and 'Sunki' mandarins, 'Carrizo' citrange, and 'Caipira DAC' sweet orange (Table 5). In other studies, 'Carrizo' citrange also induced the high fruit mass for 'Okitsu' satsuma mandarin (CANTUARIAS-AVILÉS et al., 2010; TAZIMA et al., 2013). The lowest fruit mass obtained in this study was $155.3 \mathrm{~g}$ for fruits of 'Okitsu' satsuma mandarin fruits on 'Trifoliate' orange (Table 5). However, Haas et al. (2008) reported fruit mass of $124.5 \mathrm{~g}$ for the same mandarin on the same rootstock.

The longitudinal diameter of the fruit had values ranging from 60.0 through $64.0 \mathrm{~mm}$, whereas the equatorial diameter ranged from 69.0 through 76.0 $\mathrm{mm}$ (Table 5). However, there was no significative difference on the size of the fruits of 'Okitsu' satsuma mandarin from trees on the different rootstocks (Table 5). The size of the mandarin is an important issue for the growers, as the Brazilian consumers prefer larger fruits (CRUZ et al., 2010). Furthermore, the fruits of 'Okitsu' satsuma mandarin produced by the trees on all rootstocks tested in the present work had acceptable commercial sizes for the Brazilian fresh fruit market, as they could be placed in the 66, 70, and 74 classes (CEAGESP, 2000).

Regarding fruit quality, the total soluble solids ranged from 9.11 to $10.11^{\circ} \mathrm{Brix}$, total titratable acidity from 0.88 to $1.13 \%$, SST/TTA ratio from 8.82 to 10.87 , and juice content from 44.7 to $49.7 \%$ (Table 5). The Brazilian program for improving fresh fruit standards indicated that acceptable consumption rates should be for soluble solids between 9.0 and $10.5^{\circ}$ Brix, SST/TTA ratio between 8.5 and 9.5, and juice content between 35 and $42 \%$, for the mandarin group (CEAGESP, 2000). The 'Okitsu' satsuma mandarin fruits produced by the trees on all different rootstocks were within the accepted values for the Brazilian fresh fruit market, though some statistical differences have been observed as discussed below. 
Table 5. Mass, longitudinal diameter (LD) and equatorial diameter (ED) of the fruits, total soluble solids (TSS), total titratable acidity (TTA), ratio (TSS/TTA), juice content (JC), and technological index (TI) of 'Okitsu' satsuma mandarin fruits from trees grafted on different rootstocks in Paranavaí, PR, for the period from 2006 through 2010.

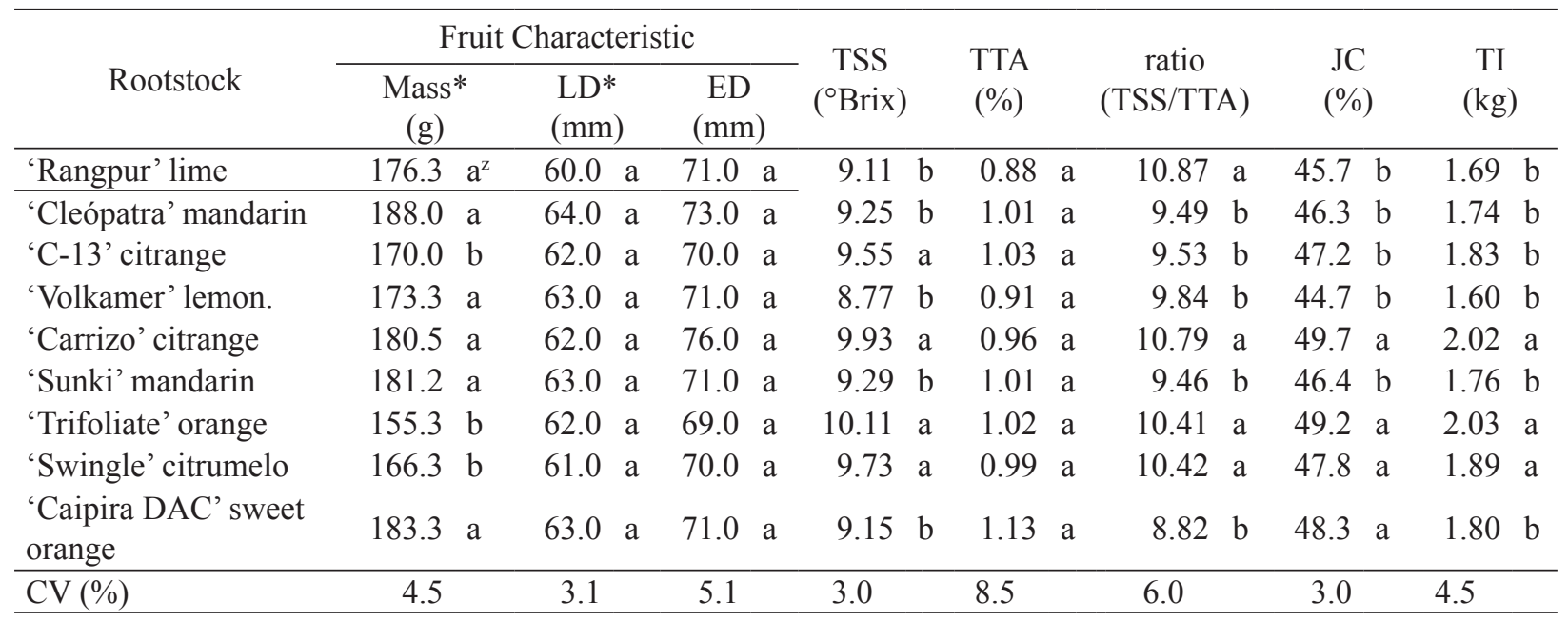

${ }^{\mathrm{z}}$ Means followed by the same letter in the column are not significantly different at 0.05 level by Scott-Knott test.

*Except 2009.

Source: Elaborated by the authors.

The highest content of total soluble solids was observed on fruits from trees grafted on 'C-13' and 'Carrizo' citrange, 'Trifoliate' orange and 'Swingle' citrumelo, ranging from 9.55 through $10.11{ }^{\circ}$ Brix (Table 5). These contents of total soluble solids are similar to the values of 9.8 and 9.67 obtained by Haas et al. (2008) and Tazima et al. (2013), respectively, mainly for 'Okitsu' satsuma mandarin grafted on 'Trifoliate' orange. This rootstock and its hybrids are known to induce higher levels of soluble solids in citrus fruits (POMPEU JUNIOR, 2005).

The rootstocks included in this study did not induce differences in the total acidity of the fruit juice, which ranged from 0.88 to $1.13 \%$ (Table 5). However, total acidity values below 1.0 at the harvest time were obtained for fruits from trees on 'Rangpur' lime, 'Volkamer' lemon, 'Carrizo' citrange and 'Swingle' citrumelo (Table 5). These results indicate earliness of maturation for the fruits of 'Okitsu' satsuma mandarins, which may be interesting from a commercial point of view. Further, Bini et al. (2009) reported that later crops could reduce total acidity, providing an increase in the TSS/TTA ratio, which would be desirable.
The highest TSS/TTA ratio, between 10.41 and 10.87, was observed for fruits from trees on 'Rangpur' lime, 'Carrizo' citrange, 'Trifoliate' orange, and 'Swingle' citrumelo (Table 5). These ratios are similar to those obtained by Haas et al. (2008). Tazima et al. (2013) obtained a TSS/TTA ratio of 14.17 and 14.67 for fruits from 'Okitsu' satsuma mandarin trees on 'Trifoliate' orange and 'Carrizo', respectively. Oliveira et al. (2005), reported a fruit mass of $209.0 \mathrm{~g}$, total soluble solids of $9.2{ }^{\circ} \mathrm{Brix}$, total acidity of $0.56 \%$, TSS/TTA ratio of 16.62 and juice content of $42.2 \%$ for fruits of 'Okitsu' satsuma mandarin. These values were probably due to climatic conditions where they carried out the study, as the climate factors play a major role in determining fruit quality (TUBELIS, 1995).

Two clearly distinct groups were formed based on juice content. The rootstocks that induced the highest juice content in the fruits, ranging from 47.8 to $49.7 \%$, were 'Carrizo' citrange, 'Trifoliate' orange, 'Swingle' citrumelo, and 'Caipira DAC' sweet orange, while the other rootstocks induced a juice content significantly lower (Table 5). Tazima 
et al. (2013) also observed two major groups of rootstocks in relation to juice content in the fruits produced by the 'Okitsu' satsuma mandarin trees, with 'Carrizo', 'Trifoliate' orange, 'Cleópatra' mandarin and 'Swingle' citrumelo standing out, with juice contents from 46.5 to $47.4 \%$. With the exception of 'Caipira DAC' sweet orange, the rootstocks that induced the highest juice content in the fruits were the same that provided fruits with the highest technological index (Table 5). However, no significant differences has been observed in juice content for fruits of 'Okitsu' satsuma mandarin from trees on 'Rangpur' lime and 'Sun Chu Sha Kat' mandarin (CANTUARIAS-AVILÉS et al., 2010).

Only fruits produced by 'Okistu' satsuma mandarin trees grafted on 'Volkamer' lemon rootstock would have some restriction regarding their quality to attend the minimal standards acceptable for fruits of mandarins established for the state of São Paulo and the Triângulo Mineiro region (CEAGESP, 2000). The minimal levels are $35 \%$ for juice content, $9.0{ }^{\circ}$ Brix for total soluble solids, and 8.5 for the TSS/TTA ratio (CEAGESP, 2000). However, the 9.84 TSS/TTA ratio obtained for fruits of trees on this rootstock is acceptable (Table 5).

In terms of the parameters for planning orchards, based on the vegetative growth of 'Okitsu' satsuma mandarins trees, the 'Cleópatra' mandarin rootstock requires the largest spacing between rows and between trees, with $7.1 \mathrm{~m}$ and $3.4 \mathrm{~m}$, respectively (Table 6). This spacing differed significantly from the ones obtained for trees on the other rootstocks. In contrast, 'Trifoliate' orange was the rootstock that provided the lowest values, with $5.3 \mathrm{~m}$ between rows and 2.1 between trees (Table 6). On the other hand, 'Trifoliate' orange was the rootstock that provided the largest number of trees per unit of area, with 917.3 trees per hectare (Table 6). Further, high planting density by using small tree size has been a tendency in citrus production with the main objective to optimize productivity (STUCHI; GIRARDI, 2011).

For trees on Swingle citrumelo, theoretically, it would be appropriate to have 701.3 trees ha-1 ${ }^{-1}$, while for the rootstock 'Cleópatra' mandarin the number of trees would be 413.2 trees ha' ${ }^{-1}$ (Table 6). For the variables of productive efficiency and theoretical productivity, no significant differences were observed among the rootstocks for trees of Okitsu satsuma mandarin (Table 6).

The productive efficiency ranged from $7.0 \mathrm{~kg} \cdot \mathrm{m}^{-3}$ of canopy, for trees on 'Cleópatra' mandarin, to 12.9 $\mathrm{kg} \cdot \mathrm{m}^{-3}$ for the ones on 'Trifoliate' orange (Table 6). Regarding the theoretical productivity, the means ranged from $95.6 \mathrm{t} \cdot \mathrm{ha}^{-1}$ for trees on ' $\mathrm{C}$-13' citrange up to $152.1 \mathrm{t} \cdot \mathrm{ha}^{-1}$ for those on 'Carrizo' citrange (Table 6). In other study, the highest productive efficiency was observed for trees on 'Flying Dragon' rootstock, while the lowest yield efficiency was obtained for trees grafted on 'Sunki' and 'Sun Chu Sha Kat' mandarins, 'Carrizo' citrange, and 'Orlando' tangelo (CANTUARIAS-AVILÉS et al., 2010). 
Table 6. Theoretical requirements for spacing between rows and between trees, number of trees ha $^{-1}$, productive efficiency and productivity for 'Okitsu' satsuma mandarin grafted on different rootstocks, based on parameters proposed by De Negri and Blasco (1991).

\begin{tabular}{|c|c|c|c|c|c|c|c|}
\hline \multirow{3}{*}{$\begin{array}{l}\text { Rootstock } \\
\text { 'Rangpur' lime }\end{array}$} & \multicolumn{3}{|c|}{ Spacing $(\mathrm{m})$} & \multirow{2}{*}{\multicolumn{2}{|c|}{$\begin{array}{c}\text { Number of } \\
\text { trees ha-1 }\end{array}$}} & \multirow[b]{2}{*}{$\begin{array}{c}\text { Productive } \\
\text { efficiency }\left(\mathrm{kg} \cdot \mathrm{m}^{-3}\right)\end{array}$} & \multirow[b]{2}{*}{$\begin{array}{l}\text { Productivity } \\
\left(\mathrm{t} \cdot \mathrm{ha}^{-1}\right)\end{array}$} \\
\hline & \multicolumn{2}{|c|}{$\begin{array}{c}\text { Between } \\
\text { rows }\end{array}$} & Between trees & & & & \\
\hline & 6.6 & $b^{z}$ & $3.1 \mathrm{~b}$ & 497.6 & $\mathrm{c}$ & $8.2 \mathrm{a}$ & $107.4 \mathrm{a}$ \\
\hline 'Cleópatra' mandarin & 7.1 & $\mathrm{a}$ & $3.4 \mathrm{a}$ & 413.2 & $\mathrm{c}$ & $7.0 \mathrm{a}$ & $108.2 \mathrm{a}$ \\
\hline 'C-13' citrange & 6.6 & $\mathrm{~b}$ & $3.1 \mathrm{~b}$ & 497.3 & $\mathrm{c}$ & $7.4 \mathrm{a}$ & $95.6 \mathrm{a}$ \\
\hline 'Volkamer' lemon & 6.3 & $\mathrm{~b}$ & $2.9 \mathrm{~b}$ & 552.0 & $\mathrm{c}$ & $10.5 \mathrm{a}$ & $131.9 \mathrm{a}$ \\
\hline 'Carrizo' citrange & 6.3 & $\mathrm{~b}$ & $2.8 \mathrm{~b}$ & 564.0 & $\mathrm{c}$ & $10.9 \mathrm{a}$ & $152.1 \mathrm{a}$ \\
\hline 'Sunki' mandarin & 6.2 & $\mathrm{~b}$ & $2.7 \mathrm{~b}$ & 590.2 & $\mathrm{c}$ & $8.0 \mathrm{a}$ & $116.1 \mathrm{a}$ \\
\hline 'Trifoliate' orange & 5.3 & $\mathrm{~d}$ & $2.1 \mathrm{~d}$ & 917.3 & $\mathrm{a}$ & $12.9 \mathrm{a}$ & $113.4 \mathrm{a}$ \\
\hline 'Swingle' citrumelo & 5.8 & $\mathrm{c}$ & $2.5 \mathrm{c}$ & 701.3 & $\mathrm{~b}$ & $10.3 \mathrm{a}$ & $120.2 \mathrm{a}$ \\
\hline $\begin{array}{l}\text { 'Caipira DAC' sweet } \\
\text { orange }\end{array}$ & 6.4 & $\mathrm{~b}$ & $2.9 \mathrm{~b}$ & 533.9 & $\mathrm{c}$ & $10.4 \mathrm{a}$ & 150.0 a \\
\hline $\mathrm{CV}(\%)$ & 3.5 & & 5.5 & 9.7 & & 26.1 & 22.7 \\
\hline
\end{tabular}

${ }^{z}$ Means followed by the same letter in the column are not significantly different at 0.05 level by Scott-Knott test.

Source: Elaborated by the authors.

\section{Conclusions}

The smallest tree canopy volume for 'Okitsu' satsuma mandarin trees is induced by the 'Trifoliate' orange rootstock, while the largest is induced by 'Cleópatra' mandarin.

'Volkamer' lemon, 'Rangpur' lime, 'Caipira DAC' sweet orange, 'Cleópatra' mandarin, and 'Carrizo' citrange induce the highest cumulative yields, and, including 'Sunki' mandarin, the fruits 'Okitsu' satsuma mandarin produced by trees on these rootstocks have the largest mass.

Fruits of 'Okitsu' satsuma mandarin produced by trees grafted on 'Rangpur' lime, 'Carrizo' citrange, 'Trifoliate' orange', and 'Swingle' citrumelo have the highest content of juice and TSS/TTA ratio.

\section{Acknowledgments}

We thank the staff of the Londrina and Paranavaí Experimental Stations of the Agronomic Institute of Paraná for their assistance in conducting the experiment and data collection, and the National Council for Scientific and Technological
Development (CNPq) for the Fellowship in Productivity in Research awarded to Carmen Silvia V. J. Neves.

\section{References}

ASSOCIATION OF OFFICIAL ANALYTICAL CHEMISTS - AOAC. Official methods of analysis. $15^{\text {th }}$ ed. Arlington: Kenneth, H., 1990. 1298 p.

BARBASSO, D. V.; PIO, R. M.; CARVALHO, S. A. Compatibilidade de variedades e híbridos de tangerinas enxertadas em citrumelo 'Swingle'. Laranja, Cordeirópolis, v. 26, n. 1, p. 59-67, 2005.

BINI, D. A.; MARTINS, C. R.; AMARAL, U.; BRIXNER, G. F.; OLIVEIRA, D. B. Comportamento agronômico de tangerineira 'Clemenules' e de laranjeira 'Salustiana' no município de Uruguaiana-RS. Revista da FZVA, Uruguaiana, v. 16, n. 2, p. 288-301, 2009.

CANTUARIAS-AVILÉS, T.; MOURÃO FILHO, F. A. A.; STUCHI, E. S.; SILVA, S. R.; ESPINOZA-NÚÑEZ, E. Tree performance and fruit yield and quality of 'Okitsu' Satsuma mandarin grafted on 12 rootstocks. Scientia Horticulturae, Amsterdam, v. 123, n. 3, p. 318$322,2010$.

COMPANHIA DE ENTREPOSTOS E ARMAZÉNS GERAIS DE SÃO PAULO - CEAGESP. Classificação das Tangerinas. São Paulo: CEAGESP, 2000. 1 folder. 
CRUZ, M. C. M.; RAMOS, J. D.; MOREIRA, R. A.; SANTOS, V. A. Crescimento de tangerinas 'Ponkan' em plantas submetidas ao raleio químico. Revista Ceres, Viçosa, v. 57, n. 4, p. 500-505, 2010.

DE NEGRI, J.D.; BLASCO, E. E.A. Planejamento e implantação de um pomar cítrico. In: RODRIGUEZ, O.; VIÉGAS, F. C. P. (Ed.). Citricultura brasileira. 2. ed. Campinas: Fundação Cargill, v. 1, 1991. p. 318-332.

DI GIORGI, F.; IDE, B. Y.; DIB, K.; MARCHI, R. J.; TRIBONI, H. R.; WAGNER, R. L. Contribuição ao estudo do comportamento de algumas variedades de citros e suas implicações agroindustriais. Laranja, Cordeirópolis, v. 11, n. 2, p. 567-612, 1990.

FADAMIRO, H.; NESBITT, M.; WALL, C. Crop profile for Satsuma mandarin in Alabama: production facts. Raleigh: USDANIFA, 2007. Disponível em: <http://www. ipmcenters.org/cropprofiles/docs/ALSatsumamandarin. pdf $>$. Acesso em 16 jun. 2011.

FERREIRA, D. F. Manual do sistema Sisvar para análises estatísticas. Lavras: UFLA, 2000. 66 p.

HAAS, L. B.; SCHNEIDER, E. P.; PICOLOTTO, L. Produção e qualidade dos frutos das cultivares de tangerina promissoras para o sul do estado do rio Grande do Sul. In: CONGRESSO DE INICIAÇÃO CIENTÍFICA, 17; ENCONTRO DE PÓS-GRADUAÇÃO, 10., 2008, Pelotas. Anais... Pelotas: UFPEL, 2008. Disponível em: $<$ http://www.ufpel.edu.br/cic/2008/cd/pages/pdf/CA/ CA_01249.pdf >. Acesso em: 17 jun. 2011.

INSTITUTO AGRONÔMICO DO PARANÁ - IAPAR. A citricultura no Paraná. Londrina: IAPAR, 1992. 288 p. (IAPAR. Circular, 72).

Estações meteorológicas. Londrina: IAPAR, 2011. Disponível em: <http://www.iapar.br/arquivos/ Image/monitoramento/Medias_Historicas/londrina. htm>. Acesso em: 16 nov. 2011.

INSTITUTO BRASILEIRO DE GEOGRAFIA E ESTATÍSTICA - IBGE. Estados@: O Brasil estado por estado. 2014. Disponível em: <http://www.ibge.gov.br/ estadosat/temas.php?sigla $=$ pr\&tema $=$ lavourapermanen te2012>. Acesso em: 26 maio 2014.

MENDEL, K. Rootstock-scion relationships in Shamouti trees on light soil. Ktavim, Rehovot, v. 6, n. 1, p. 35-60, 1956.

MORAES, C. Tecnologia: beleza e manejo. Frutas e Derivados, São Paulo, v. 2, n. 6, p. 30-32, 2007. Disponível em: <http://www.ibraf.org.br/x_files/ revista06.pdf>. Acesso em: 12 out. 2011.

MOURÃO FILHO, F. A. A.; ESPINOZA-NÚÑEZ, E.; STUCHI, E. S.; ORTEGA, E. M. M. Plant growth, yield, and fruit quality of 'Fallglo' and 'Sunburst' mandarins on four rootstocks. Scientia Horticulturae, Amsterdam, v. 114 , n. 1, p. 45-49, 2007.
NODA, K.; OKUDA, H.; KIHARA, T.; IWAGAKI, I.; KAWASE, K. Effects of rootstocks on tree growth and fruit quality in very early ripening Satsuma mandarin 'Yamakawa'. Journal of the Japanese Society for Horticultural Science, Tokyo, v. 70, n. 1, p. 78-82, 2001.

NOGUEIRA, D. J. P. O clima na citricultura. Informe agropecuário, Belo Horizonte, v. 5, n. 52, p. 3-15, abr. 1979.

OLIVEIRA, R. P.; CANTILLANO, R. F. F.; MALGARIM, M. B.; TREPTOW, R. O.; GONÇALVES, A. S. Características dos citros apirênicos produzidos no Rio Grande do Sul. Pelotas: Embrapa Clima Temperado, 2005. 41 p. (Embrapa Clima Temperado. Documentos, 141).

OLIVEIRA, R. P.; SOARES FILHO, W. S.; PASSOS, O. S.; SCIVITARO, W. B.; ROCHA, P. S. G. Porta-enxertos para citros. Pelotas: Embrapa Clima Temperado, 2008. 45 p. (Embrapa Clima Temperado. Documentos, 226).

PEARCE, S. C.; DOBERSEK-URBANC, S. The measurement of irregularity in growth and cropping. Journal of Horticultural Science, Ashford Kent, v. 42, n. 3, p. 295-305, 1967.

POMPEU JÚNIOR, J. Porta-enxertos. In: MATTOS JÚNIOR, D.; DE NEGRI, J. D.; PIO, R. M.; POMPEU JÚNIOR, J. (Org.). Citros. Campinas: Instituto Agronômico e Fapesp, 2005. p. 63-104.

Porta-enxertos. In: RODRIGUEZ, O.; VIÉGAS, F.; POMPEU JÚNIOR, J.; AMARO, A. A. (Ed.). Citricultura Brasileira. Campinas: Fundação Cargill, 1991. p. 264-280.

ROSSETTI, V. V. Manual ilustrado de doenças dos citros. Piracicaba: Fealq/Fundecitrus. 2001. 207 p.

STATISTICAL ANALYSIS SYSTEM INSTITUTE - SAS. SAS INSTITUTE. SAS/STAT User's guide. Version 8.2. Cary, NC: Statistical Analysis System Institute, 2001. $943 \mathrm{p}$.

STUCHI, E. S.; GIRARDI, E. A. Adensamento de plantio deve ser o quarto elemento no manejo do HLB. Citricultura Atual, Cordeirópolis, v.14, n. 81, p. 12-16, 2011.

TAZIMA, Z. H.; LEITE JÚNIOR, R. P. Novos cultivares de citros recomendados para o Paraná. In: CONGRESSO BRASILEIRO DE FRUTICULTURA, 17., Belém, 2002. Anais... Belém: SBF, 2002. CD-ROM.

TAZIMA, Z. H.; NEVES, C. S. V. J.; YADA, I. F. U.; LEITE JÚNIOR, R. P. Performance of 'Okitsu' satsuma mandarin on nine rootstocks. Scientia Agricola, Piracicaba, v. 70, n. 6, p. 422-427, nov./dez. 2013.

TUBELIS, A. Clima: fator que afeta a produção e a qualidade da laranja. Laranja, Cordeirópolis, v. 16, n. 2, p. 179-211, 1995. 